Огляди літератури, оригінальні дослідення, погляд на проблему

УДК 616-001:612.015

DOI

\title{
ОСОБЛИВОСТІ ПЕРЕБІГУ ПОЛІТРАВМИ У РІЗНОМУ ВІЦІ
}

ОГ. М. Степанова

\section{Черкаський медичний коледж}

РЕЗЮМЕ. У статті представлено значення проблеми перебігу політравми у пацієнтів різного віку. У результаті огляду літератури показаночастоту виникнення політравми, смертність відполітравм. Наголошено, що травматизм найбільш поширений серед дітей та осіб працездатного віку. У дітей при політравмі найчастіше спостерігаються поранення нижніх кінцівок і черепно-мозкові травми, а у дорослих - крім цього, ще й ушкодження верхніх кінцівок, травми грудної клітки і черевної порожнини, переломи таза, розриви сечового міхура й ушкодження шийного відділу хребта. Серед осіб літнього віку рівень травматизму значно нижчий, ніж у молодших категорій населення, проте травми супроводжуються високою летальністю. Показана актуальність проблеми політравми у зв'язку із веденням бойових дій. Зроблено висновок про важливість і актуальність дослідження особливостей політравм у осіб різного віку. Продемонстровано, що дослідження біохімічних процесів, пов' язаних із розвитком травматичної хвороби, має переважно дотичний характер.

КЛЮчОВІ СЛОВА: травматизм, політравма, травматична хвороба, віковий розподіл.

Вступ. Травматизм $є$ однією з основних причин тривалої непрацездатності у промислово розвинених країнах і країнах, що розвиваються. Наразі травма, як причина смерті, обіймає третє місце, поступаючись серцево-судинним та онкологічним захворюванням $[9,8]$. Прогнозується, що до 2020 року тяжкі травми випередять багато інших хвороб у статусі основної причини смерті та інвалідності [17]. Водночас, на відміну від серцево-судинних та онкологічних хвороб, проблему травматизму розв'язати легше, оскільки суспільство має більші резерви як у запобіганні травм, так і в боротьбі з наслідками $[12,23]$. На жаль, ці резерви суспільство використовує недостатньо, оскільки за останнє десятиліття, згідно з даними ВООЗ, частота політравми збільшилася на $15 \%$. В Україні щорічно травми різного ступеня тяжкості отримує близько $10 \%$ населення [11]. Смертність від нещасних випадків і травм в Україні зростає в середньому на $1 \%$ щорічно [4].

Як зазначив відомий нейрохірург Леонід Ліхтерман, сьогодні травматизм - це складна мультидисциплінарна проблема на стику медицини і соціології, одна з найбільш значущих в охороні здоров'я. Це обумовлено масовістю поширення тяжких травм, високою летальністю та інвалідизацією постраждалих, тяжкістю наслідків і втратою працездатності, надзвичайно економічно обтяжливою для родини і суспільства, переважною антропогенністю та техногенністю [9].

Тягар, який накладає на суспільство травматизм, проявляється в усьому світі, а особливо-в країнах із низьким і середнім доходом населення, де більше чинників ризику виникнення травм (йдеться передусім про дорожньо-транспортні пригоди та збройні конфлікти) і менш підготовлена для лікування травм система охорони здоров'я
$[17,18]$. Згадані причини обумовлюють значну актуальність заходів із боротьби з травматизмом в Україні. До традиційно високого рівня ДТП, що фіксується в Україні, в 2014 році додалася війна на Сході, котра фактично відродила військову медицину, орієнтовану передусім на лікування воєнних травм [1] (М.І. Пирогов характеризував війну як травматичну епідемію). Частина дослідників наголошує на подібності тяжкої травми в мирному житті й бойового поранення, причому перша може слугувати клінічною моделлю другого [3].

у 9-15 \% випадків травмувань виникає множинна та поєднана травма - політравма, летальність при якій сягає 22-24 \% [14, 12]. У 25-45\% випадків наслідком політравми стає інвалідність. Пацієнти 3 політравмами становлять 8-10\% від усіх стаціонарних хворих і дають до 70 \% усіх летальних наслідків травм [2]. Середній вік пацієнтів із політравмами - 38,5 року [15].

Оскільки політравма спричиняє низку адаптивних і патологічних процесів, до наукового обігу введено поняття травматичної хвороби (ТX) [12, 22]. Як зазначають дослідники, умови виникнення політравм (ДТП, бойові дії, виробничий травматизм, падіння з висоти, злочинні напади тощо) спричинюють механічні та опікові ушкодження як вісцеральних органів, так і кісток, м'язів, шкірних покривів. Усе це може викликати різноманітні ускладнення, в тому числі приєднання інфекцій $[12,5]$.

При політравмі додавання ушкоджувальних чинників стає не арифметичною сумою тяжкості окремих компонентів травми чи окремих ї̈ складових. Основою патогенезу травми $\epsilon$ закон взаємного обтяження, через що один вид ушкодження погіршує перебіг іншого виду ушкодження. TX охоплює практично весь організм, усі ланки ре- 
Огляди літератури, оригінальні дослідження, погляд на проблему

гуляції. Причинами ушкоджень великої кількості органів, у тому числі нетравмованих, є гіперкатехоланемія, активація вільнорадикального окиснення, ендотоксикоз, синдром дисемінованого внутрішньосудинного згортання (ДВЗ-синдром), гіпоксія [13].

У проблемі травматизму помітний віковий аспект - як із погляду поширеності, так і з погляду тяжкості наслідків.

Найбільше поширення травматизм має серед дітей та осіб працездатного віку. У цих категорій населення травматизм як причина смерті та інвалідності сильно випереджає і серцево-судинні захворювання (у 10 разів), і новоутворення (у 20 разів) $[9,8]$. Взагалі, у віці від 1 до 45 років у чоловіків і від 1 до 35 років у жінок нещасні випадки є основною причиною смерті [15], а серед підлітків та юнаків цей показник, за деякими даними, сягає 80 \% [3]. У дітей при політравмі найчастіше спостерігаються поранення нижніх кінцівок і черепно-мозкові травми, а у дорослих - крім цього, ще ушкодження верхніх кінцівок, травми грудної клітки і черевної порожнини, переломи таза, розриви сечового міхура й ушкодження шийного відділу хребта. Серед осіб літнього віку рівень травматизму значно нижчий, ніж у молодших категорій населення, проте травми супроводжуються високою летальністю, яка у 5 разів перевищує летальність в більш молодих вікових групах $[12,23]$.

Відповідно до рекомендацій ВОО3, смертність від травм обраховують не тільки за фактичною кількістю загиблих, а й за роками «недожитого» життя. Приміром, якщо в країні середня тривалість життя 70 років, то загибель 20-річної жінки в автокатастрофі за цим показником може відповідати смерті від природних хвороб 50-ти осіб. Відповідно до цієї методики обрахунку, дослідження, проведене в середині 1990-х років у пострадянських країнах, показало, що середні втрати від травм виявилися у 2,7 разів більші, ніж від хвороб серцево-судинної системи та новоутворень, разом узятих [15]. Відомо також, що для травматичних уражень характерна перевага осіб чоловічої статі в будь-якому віці, починаючи з малечого. Однак якщо в дитячому віці ця різниця невелика, то після 20 років чоловіки гинуть у декілька разів частіше за жінок (наприклад, у віці 50-54 років - у 4,4 раза частіше) [15].

Усі ці аспекти обумовлюють важливість і актуальність дослідження особливостей політравм у осіб різного віку.

Вікові особливості перебігу окиснювальних процесів успішно досліджують на щурах - із урахуванням еквівалента віку щурів та людини (табл. 1) [6].

Таблиця 1. Вікові особливості перебігу окиснювальних процесів у щурів та людини з урахуванням еквівалента віку

\begin{tabular}{|l|c|c|}
\hline \multicolumn{1}{|c|}{ Період життя } & Вік щурів, міс. & Вік людини, р. \\
\hline Ранній молочний & 0,25 & 0,35 \\
\hline Середній молочний & 0,50 & 1,56 \\
\hline Пізній молочний & 1,00 & 4,30 \\
\hline Препубертатний & $2,00-3,00$ & $10,24-14,20$ \\
\hline Пубертатний & 4,00 & 17,39 \\
\hline Репродуктивний & $5,00-7,00$ & $20,08-24,63$ \\
\hline
\end{tabular}

Частина дослідників застосовує метод клінічного спостереження $[11 ; 16]$. Разом із тим, дослідження проводять переважно із залученням представників вікової групи від 20 до 40 років [7].

Встановлено чітку залежність між віком і рівнем летальності у постраждалих з політравмою. що старше постраждалі, тим вища летальність, причому між віком і рівнем летальності існує сильна лінійна кореляція $(r=0,987)$. Максимальна летальність (30 \%) спостерігається серед чоловіків у віковій групі старше 61 року $[16,8]$.

Низка дослідників торкаються проблем вікових особливостей перебігу окиснювальних процесів. Зокрема, з'ясовано, що вікові особливості мають концентрація цитохрому P-450 та активність процесів гідроокиснювання в мікросомах печінкових клітин (як відомо, печінка належить до числа органів, що піддаються найбільшому ураженню внаслідок ТХ) [10]. Також встановлено, що вікові особливості має залежність вираженості ушкоджувальної дії радикальних продуктів від інтенсивності їх продукування та швидкості знешкодження антиоксидантною системою. Вказується на пригнічення у старості інтенсивності радикалоутворення і зниження концентрації субстратів ліпопероксидації. Однак з віком знижується також функціональна активність антиоксидантної системи, що сприяє впливу радикалів на клітинні структури [6].

Висновок. Дослідження біохімічних процесів, пов'язаних із розвитком ТХ, має переважно дотичний характер. Разом із тим, у зв'язку з тим, 
Огляди літератури, оригінальні дослідженн, погляд на проблему що доведено чітку залежність тяжкості перебігу травматичної хвороби від віку пацієнтів, $\epsilon$ на-

гальна потреба продовження досліджень у цій царині.

\section{ЛІТЕРАТУРА}

1. Антонюк А. Як втамувати біль бійця АТО: вимушений апгрейд анестезіологічного напрямку медицини / А. Антонюк // Український медичний часопис. 2015. - № 1. - С. 6-8.

2. Бадінов О. В. Сучасні уявлення про патогенез ендотоксикозу посттравматичного генезу / О. В. Бадінов, В. Д. Лук'янчук, Л. В. Савченкова // Современные проблемы токсикологии. - 2003. - № 4. - С. 10-16.

3. Гайдук С. В. Клинико-патофизиологическое обоснование ранней диагностики синдрома полиорганной недостаточности и висцеральных осложнений у пострадавших с политравмой: дисс. на соискание ученой степени доктора медицинских наук: 14.00.16 и 14.00.05 / Гайдук Сергей Валентинович. - СПб., 2009. - 389 с.

4. Гайко П. В. Стан ортопедо-травматологічної служби і перспективи їі розвитку в Україні // XII з'їзд травматологів-ортопедів України : матеріали з'їзду. Київ, 1996. - С. 1-2.

5. Гуманенко Е. К. Достижения в лечении тяжелой сочетанной травмы за последние 20 лет / Е. К. Гуманенко, А. Б. Сингаевский // Скорая медицинская помощь. 2004. - T. 5, № 3. - С. 153-154.

6. Кліщ І. М. Вікові особливості перебігу окиснювальних процесів за умов токсичного ураження печінки та способи їх корекції: дис. на здобуття наукового ступеня д-ра біол. наук: 03.00.04 / Кліщ Іван Миколайович. - Львів, 2003. - 372 с.

7. Кудлай Д. А. Иммунобиологические аспекты патогенеза политравмы: дисс. на соискание ученой степени д-ра медицинских наук / Кудлай Дмитрий Анатольевич. - Новосибирск, 2007. - 242 с.

8. Левченко Т. В. Анализ госпитальной летальности и качества клинической диагностики у пострадавших с политравмой / Т. В. Левченко, С. А. Кравцов, А. Н. Корнев // Политравма. - 2014. - № 3. - С. 24-40.

9. Лихтерман Л. Б. Черепно-мозговая травма / Л. Б. Лихтерман. - М. : Медицинская газета, 2003. - 358 с.

10. Парамонова Г. И. Регуляция микросомального окисления в печени при старении: дис. на соискание ученой степени д-ра биол. наук: 03.00.04 / Парамонова Галина Ивановна. - К., 1994. - 299 с.

11. Підгайний Ю. Л. Динаміка біохімічних показників сироватки крові при травматичних пошкодженнях нирок / Ю. Л. Підгайний // Запорожский медицинский журнал. - 2014. - № 6. - С. 28-31.

12. Підручна С. Р. Патогенетичне обґрунтування ксенодермотрансплантації у системній корекції морфофункціональних змін внутрішніх органів на тлі комбінованої (механічної і термічної) травми: дис. ... д-ра медичних наук: 14.03.04 / Підручна Світлана Романівна. - Тернопіль, 2013. - 347 с.

13. Политравма. Поражение сердца / А. Н. Нудьга, Е. И. Киношенко, В. А. Галинская [и др.] // Медицина неотложных состояний. - 2006. - № 6 (7). - С. 69-70.

14. Секела Т. Я. Патогенетичні особливості перебігу тяжкої травми в поєднанні з механічним пошкодженням шкіри та при застосуванні ксенодермопластики: дис. на здобуття наукового ступеня кандидата медичних наук: 14.03.04 / Секела Тетяна Ярославівна. Тернопіль, 2010. - 181 с.

15. Соколов В. А. Социальное значение множественных и сочетанных травм / В. А. Соколов // Bone-surgery: Портал о хирургии костной ткани - Режим доступу до матеріалу: http://bone-surgery.ru/view/socialnoe_ znachenie_mnozhestvennyh_i_sochetannyh_travm/

16. Шаталин А. В. Основные факторы, влияющие на летальность у пациентов с политравмой транспортированных в специализированный травматологический центр / А. В. Шаталин, С.А. Кравцов, В.В. Агаджанян // Политравма. - 2012. - № 3. - С. 17-36.

17. The impact of traumatic brain injuries: a global perspective / A.A. Hyder, C.A. Wunderlich, P. Puvanachandra [et al.] // NeuroRehabilitation. - 2007. - Vol. 22 (5). P. 341-353.

18. The costs of traumatic brain injury: a literature review / I. Humphreys, R. L. Wood, C. J. Phillips, S. Macey // Clinicoecon. Outcomes Res. - 2013. - Vol. 5. P. 281-287.

\section{PECULIARITIES OF THE POLYTRAUMA COURSE AT DIFFERENT AGES}

○ H. M. Stepanova

\section{Cherkasy Medical Colledge}

SUMMARY. The article deals with problems of the process of polytrauma of patients of different ages. As a result of review of the literature it shows the incidence and mortality of polytrauma. It emphasized that injuries are most common among children and people of working age. In polytrauma children often seen injuries of the lower extremities and head injuries, and adults - in addition injuries of the upper extremities, chest and abdominal traumas, pelvic fractures, ruptures the bladder and cervical spine injury. Among elderly injury rate significantly lower than in younger populations, but injuries are accompanied by high mortality. In the article it shows the actuality of potytrauma problems in connection with the conduct of combat operations. It is concluded about the importance and relevance of research of features of polytrauma of people of all ages. However, it is demonstrated that the study of biochemical processes associated with the development of traumatic disease has mainly tangential character.

KEY WORDS: injury, polytrauma, traumatic disease, age distribution. 